UDC $316+614(470)$

DOI: $10.21668 /$ health.risk/2019.4.19.eng

\title{
ROLE PLAYED BY A FAMILY IN CREATING HEALTHY LIFESTYLE AND ELIMINATING RISK FACTORS THAT CAUSE THREATS TO CHILDREN'S AND TEENAGERS' HEALTH
}

\section{E.N. Novoselova}

Moscow State University, 33 Bldg., 1 Leninskie Gory, Moscow, 119991, Russian Federation

The paper focuses on socializing potential than belongs to a family in creating attitudes towards health and healthy lifestyle among children and teenagers. The author describes basic behavioral risks for young people's health and a role played by the closest social environment in minimizing or aggravating them.

The author also provides an insight into concepts of health and healthy lifestyle and dwells on how important it is to perform constant monitoring over children's and teenagers' health as they represent quite a specific social and demographic group. The author analyzes data on morbidity growth among children and teenagers in Russia, how susceptible they are to addictive behavior and other risk factors, and also compares these parameters with world trends.

The latest statistical data and analysis of data available from literature allowed showing that, in spite of huge socializing potential that a family has as a social institution, at present parents are rather limited in terms of activities that can help them improve and preserve their children's health. It is caused by both transformations of a family as a social institution and weaker family relations in the contemporary world as well as by insufficient competences that parents have as regards health and overall decrease in living standards, poorer availability of medical services, unfavorable changes in the ecological situation etc.

The author concludes that it is necessary to provide support to a family as a social institution. It should be done by a state and society in general as they are to establish qualitative information channels that will allow providing parents with the latest scientific data on the most common risk factors for children's health and on ways how to minimize such risks. Any family, regardless of its social status, wealth, or any other characteristics, should be granted an opportunity to provide safety for their children.

Key words: health, health risk, healthy lifestyle, family, children, teenagers, tobacco smoking, alcohol intake, overweight and obesity, injuries, addictive behavior.

Population health is a key issue of the contemporary Russian society. It is especially alarming that health issues now occur among children and teenagers and not just among older people and it "undoubtedly contradicts any natural human development when health is deteriorated gradually as a person grows older" [1].

Population health is among the most significant signs indicating a state is truly developed; it is not only a parameter but also a most necessary condition for economic development [2-6]. Children and teenagers health is the most important as it is "the most significant indicator of a future labor, economic, cultural, and defense potential of any society" [7].
Children and teenagers' health in Russia causes a lot of concerns among medical experts, teachers and parents. Morbidity among children grows by 3.2 times faster, and among teenagers, by 4.4 times faster than among population in general [8]; mortality among children is 2 times higher in Russia than in "eight new EU countries" [9]. Over the last 15 years total morbidity among teenagers and young people grew by 1.7 times in our country [10]. According to official data, $28.9 \%$ children aged $0-14$ belong to the $1^{\text {st }}$ health group (practically healthy); $56.2 \%$, the $2^{\text {nd }}$ one (minor disorders); $12.6 \%$, the $3^{\text {rd }}$ one (non-apparent chronic diseases and congenital mal-

(C) Novoselova E.N., 2019

Elena N. Novoselova - Candidate of Sociological Sconces, Associate Professor at the Sociology Faculty (e-mail: alena_n_@mail.ru; tel.:+7(903) 666-50-44; ORCID: orcid.org/0000-0002-4010-4133). 
formations); $2.3 \%$, the $4^{\text {th }}$ and the $5^{\text {th }}$ ones (apparent chronic diseases, grave malformations, and oncology) [11]. However, these data do not show a true picture and actual children's health is significantly worse. Thus, A.A. Baranov and V.Yu. Al'bitskiy claim that "actual morbidity among children is 1.5-2 times higher than it is given by official statistics" [12].

There are a lot of various risk factors that make for health loss. However, researchers have not yet reached a common conventional opinion regarding risk factors typology, an extent to which they influence health and a nature of their influence as well as regarding procedures for examining this influence [13-17]. In any case, risk factors do not produce their effects separately but co-exist and interact with each other. Moreover, the same factor can simultaneously be a risk factor and an anti-risk one [18].

According to contemporary domestic research, children's health in Russia is significantly influenced by environmental factors (adverse environment) [19-22], biological factors (genetics) [23-25], and macro-social factors (peculiarities related to social institutions functioning, social differentiation, socioeconomic and social and political factors) [26, 27]. Behavioral health risk factors also play an important role; such factors are related to behavioral patterns that can be modified such as improper nutrition, low physical activity, smoking, alcohol intake, risky sexual behavior, etc. These and some other adverse factors related to a person's lifestyle in future will "determine morbidity and mortality among adults as well as their dynamics" [28]. It is impossible to completely eliminate behavioral health risk factors; however, an extent to which they can be minimized depends heavily on favorable environment and awareness among young generation about major health issues. And this, in its turn, depends on how competent the closest social relations are in the sphere. The primary significance here belongs to a family.

A family is a basic social institution responsible for personality formation, for a value system and a culture a person has. According to most people living in Russia $(71 \%)$, it is in a family where main personality traits are formed and where a child acquires his or her habits and attitudes in life [29]. This institution creates behavioral stereotypes that are a part of a person's lifestyle influencing his or her health: whether he or she has or doesn't have any bad habits; doing sports; nutrition habits; attitudes towards prevention and treatment of diseases; attitudes towards all other components of a healthy lifestyle. Results obtained via questioning accomplished among schoolchildren reveal that most of them think health to be the main value in life $(73.4 \%)$ and also consider a family to have a leading role in health preservation [30].

Decline in living standards, poorer availability of medical aid, adverse changes in the environment and other factors create much greater health risks and limit parents' capabilities to preserve and improve their children's health. Moreover, parents often don't have sufficient knowledge on how to educate their children regarding health preservation. Parents often tend to underestimate "how significant behavioral risk factors are as they pay too much attention to environmental risks" [31]. All the above mentioned factors, together with a family as a social institution being transformed in the contemporary world, parents being now not so authoritative as they used to be, and a gap between generations only growing, etc., lead to a significant decrease in a potential that a family has as an institution that can make for pursuing healthy lifestyle. Given that, it is quite essential to pay great attention to managing health, eliminating adverse factors, and making children and teenagers pursue healthy lifestyle.

Our research goal was to substantiate an opinion that at present as a family institution is being transformed parents don't have sufficient competence necessary for making their children healthy and convince children and teenagers to pursue a healthy lifestyle. Consequently a state and a society should provide a family with information and economic support.

The authors of the present work were most interested in studying behavioral health 
risk factors for Russian children (0-14 years old) and teenagers (15-17 years old) as they are a rather specific social and demographic group. Another important issue here is a potential that a family institution has for managing these health risk factors and their elimination.

Our empiric data were taken from a study performed by the Department for Family Sociology and Demography, Sociology Faculty of the Moscow State University. It was entitled "Inter-regional studies on life values and intransitivity of attitudes towards having a family and children among women, men, and married couples based on ongoing analysis of comparable data" (hereinafter called CeDO for short). The first stage in the study was accomplished in summer 2018 in Moscow (CeDO2018) and involved married couples questioning. The sampling included 729 people. Data were statistically processed with IBMSPSS 23.0 for Windows. In order to perform comparative analysis as well as obtain additional data on the subject, we also took data provided by the Public Opinion Fund, The Russian Public Opinion Research Center (VSIOM), the World health organization (WHO), the RF Public healthcare Ministry, and the Federal State Statistics Service (Rosstat).

Results and discussion. Healthy lifestyle is based on being educated how to preserve one's health; such education should start in the very early childhood and only in this case it will yield really good results. In this context a family is an institution that is potentially able to most efficiently instill a value-oriented approach to health in its members and minimize related risks.

As we have already mentioned, health to a great extent depends on everyday self-preserving behavior, and a person and his or her lifestyle is its mane regulator. According to data obtained via CeDO-2018, most responding parents $(63.5-62.1 \%$ fathers and $64.8 \%$ mothers) agreed with that and considered that they bore a major responsibility for their own health and health of their children. As per data provided by VSIOM, Russians also tend to blame themselves for feeling bad and their health deterioration (47\%) [32]. However, people's actions aimed at their health preservation and improvement are often contrary to their understanding what should be done to achieve this goal.

Parents believed health was on the greatest values in life. When ranking 15 values in order of priority, $46 \%$ respondents gave health the $1^{\text {st }}$ rank place $(51.9 \%$ mothers and $39.5 \%$ fathers). "health for myself" as a value had an average rank being equal to 3.2 (a bit lower than "family" as a value, 3.1 ; but the following group of values had significantly lower ranks with their average values being not less than 6). And health becomes even more valuable when it comes to children's health. When answering a question "In your opinion, what should be the most valuable for your children?" $61 \%$ respondents stated it was "health" ("health for children" as a value had a rank equal to 2.5; for comparison, "family" had only 4.8). Overall, parents didn't think their health was poor (only $1.6 \%$ mothers stated it was, and there were no fathers who gave such an answer) and considered it to be good $(53.3 \%)$. Most parents were quite satisfied with their health $(36.9 \%$ completely, and $54.1 \%$ partially) and their children's health $(51.2 \%$ completely and $40.2 \%$ partially) (Table 1 ).

Healthy lifestyle is a rather complicated and multi-dimensional concept but at the same time it is an integral one with all its elements being closely interconnected. Healthy lifestyle includes rational nutrition, giving up bad habits, physical activity, reasonable sexual behavior, diseases prevention, etc. In addition to physical and biological aspects we should also mention psychological ones such as minimizing stresses, positive thinking, ability to interact with other people etc. But at the same time it would be incorrect to reduce healthy lifestyle to individual aspects only. Sociological approaches to studying healthy lifestyle focus on social reasons, social institutions and behavioral patterns that result in occurrence of various attitudes [33].

Table 2 contains data on distribution of various healthy lifestyle elements according to opinions given by responding parents (CeDO-2018). 
Table 1

Descriptive statistics of basic CeDO-2018 results, \%

\begin{tabular}{|l|c|c|c|}
\hline \multicolumn{1}{|c|}{ Self-evaluations of health and healthy lifestyle behavior } & $\begin{array}{c}\text { Parents in } \\
\text { general }\end{array}$ & Fathers & Mothers \\
\hline Satisfied with my health (completely or partially) & 91.0 & 94.8 & 87.5 \\
\hline Satisfied with my children's health (completely or partially) & 91.4 & 94.0 & 89.1 \\
\hline Think my health is good & 53.3 & 56.0 & 50.8 \\
\hline Take regular care of my health & 41.0 & 36.2 & 45.3 \\
\hline Pursue a healthy lifestyle & 24.6 & 21.6 & 27.3 \\
\hline Try to pursue a healthy lifestyle but don't always succeed & 61.1 & 62.9 & 59.4 \\
\hline Make my children pursue a healthy lifestyle via talking to them & 36.5 & 38.8 & 34.4 \\
\hline Make my children pursue a healthy lifestyle via doing it myself & 52.0 & 47.4 & 56.3 \\
\hline Think that improper nutrition is bad for health (bad/rather bad) & 93.0 & 90.5 & 95.3 \\
\hline Think that low physical activity is bad for health (bad/rather bad) & 98.5 & 96.6 & 97.5 \\
\hline Think that alcohol intake is bad for health (bad/rather bad) & 87.3 & 81.1 & 93.0 \\
\hline Think that smoking is bad for health (bad/rather bad) & 95.9 & 93.1 & 98.5 \\
\hline Smoke & 21.7 & 31.9 & 12.5 \\
\hline Don't do sports / do it less than once a month & 32.4 & 28.3 & 31.6 \\
\hline
\end{tabular}

Table 2

Healthy lifestyle elements according to parents' opinions, in \% (CeDO-2018)

Answering a question: "What does healthy lifestyle mean to you personally?

(not more than THREE options should be chosen)"

\begin{tabular}{|l|c|c|c|}
\hline \multicolumn{1}{|c|}{ Healthy lifestyle element } & Parents in general & Fathers & Mothers \\
\hline Giving up bad habits & 65.2 & 63.8 & 66.4 \\
\hline Healthy nutrition & 63.1 & 59.5 & 66.4 \\
\hline Doing sports & 42.6 & 44 & 41.4 \\
\hline Keeping up healthy day regimen & 33.6 & 29.3 & 37.5 \\
\hline Adhering to hygiene rules & 18.0 & 14.7 & 21.1 \\
\hline No promiscuous sexual contacts & 13.5 & 12.9 & 14.1 \\
\hline Ability to manage one's emotions & 12.7 & 13.8 & 11.7 \\
\hline Regular visits to a doctor to prevent diseases & 9.4 & 6.9 & 11.7 \\
\hline Having reliable information on healthy lifestyle & 5.7 & 7.8 & 3.9 \\
\hline
\end{tabular}

Sociological concepts on health risk factors stress negative trends in lifestyles and the environment and include both behavioral risk factors and social contexts, as well as macrosociological factors (such as low living standards, "social differentiation, peculiarities of socioeconomic, social-cultural, and socialpolitical subsystems in a society") [18].

The present work primarily focuses on healthy lifestyle formation and eliminating health risks for children and teenagers. Hence, it seems advisable to pay primary attention to risk factors that can be modified such as addictive behavior, imbalanced nutrition, low physical activity, risky sexual behavior, risk of injuries, etc.
Smoking. Excess spread of smoking in Russia is a major issue related to healthy lifestyle. Smoking is a cause of untimely death in 16-17 \% cases in Russia [34]. As per data provided by the RF Public Healthcare Ministry, a number of smoking people is going down (from $37.1 \%$ in 2013 to $30.5 \%$ in 2017): however, Russia is still among outsiders as per this parameter. Smoking is more widely spread only in Indonesia, Jordan, Kiribati, and Sierra Leone [35], and a number of cigarettes per capita $(2,227)$ is one of the highest in Europe [36]. As per the WHO data, in 2017 in Russia $45 \%$ men and $15 \%$ women smoked. [37]. Selective examinations of female reproductive behavior in Russia revealed that $11.5 \%$ women didn't 
quit smoking even after they found out they were pregnant [38]. As per data obtained in international research, those women who managed to quit smoking during pregnancy were likely to start smoking again after a child was born ( $43 \%$ during the first 6 months since delivery) [39].

According to the WHO, most adults started smoking when still being teenagers. A share of smoking teenagers among those aged 13-15 is still rather high in Russia as it amounts to $15.1 \%, 17 \%$ among boys and $13.3 \%$ among girls; $26.3 \%$ out of them started smoking when they were younger than 10 [40]. There is a clear dependence between smoking parents and a wish a teenager has to start smoking. "Two thirds of teenagers from families where parents smoke or used to do it in the past have tried smoking at least once; there are much fewer such teenagers in non-smoking families, only $41 \%$ " [41]. Children who grow in families with smoking parents start smoking at an earlier age and they more often become regular smokers [42].

According to data obtained via CeDO2018, 21.7\% adults smoked among Russians who had children, $31.9 \%$ men and $12.5 \%$ women. Smoking people tended to neglect health risks caused by smoking both for them and their children (only $57 \%$ smokers believed smoking was hazardous for health against $91.7 \%$ of non-smokers). Besides, almost one fourth of smoking parents claimed that they tried to persuade their children to pursue healthy lifestyle with their own example and it was considerably lower than among non-smokers $(63.2 \%)$, but still we can say it was rather presumptuous (Figure 1). It is interesting to note that it was smokers $(40 \%)$ who believed that a healthy lifestyle required a lot of time and money against $17.5 \%$ nonsmokers being of the same opinion.

Alcohol intake. Alcohol abuse is the next health risk factor that can be modified. Contribution made by alcohol into untimely death cases amounts to about $10 \%$ [34].

According to official data provided by the RF Public Healthcare Ministry, alcohol consumption has reduced by $40 \%$ over the last

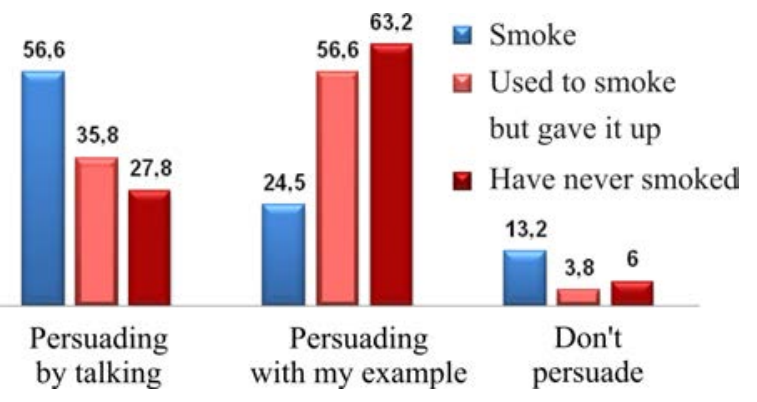

Figure 1. Persuading children and teenagers to pursue a healthy lifestyle by smoking and nonsmoking parents, in \% (CeDO-2018)

five years [43]. Data provided by the WHO confirm these statistical reports as according to them Russian now consumed by 3.5 liters fewer per capita (8.42 in 2016) than they used to 10 years ago (11.83 in 2006) [44]. Still, we should remember that these figures include only alcohol that is accounted for officially and the WHO experts believe that $30.8 \%$ alcohol consumed in Russia (3.6 liters per capita) is unaccounted for (illegal). That is, actual consumption is about 12 liters [45].

CeDO-2018 revealed that only $8.4 \%$ parents thought alcohol intake caused no health risks and didn't damage health at all; $87.3 \%$ stated it was hazardous $(51.6 \%$ believed it was extremely hazardous, and $35.7 \%$, rather hazardous, Table 1). In spite of favorable trends and population becoming aware that alcohol is a risk factor, alcohol consumption, especially strong spirits consumption, is still rather high in Russia.

VSIOM conducted a questioning in 2018 entitled "What should we protect our children from?"; it revealed that it was alcohol and drug addiciton that took the $1^{\text {st }}$ rank place with their share amounting to $37 \%$ [46]. The research also revealed that, in Russians' opinion, it was parents who bore the greatest responsibility for protecting children's interests (44\%); however, it doesn't always happen and a situation in families where a child's relatives abuse alcohol is somewhat different.

There is an undoubted relation between adults in a family being addicted to alcohol and children's health. According to data obtained via a research work performed in the USA that focused on short-term and remote 
consequences of a mother being addicted to various substances during her pregnancy, alcohol took the $1^{\text {st }}$ rank place as per adverse effects exerted on a future child's body as it left behind even such drugs as marijuana, cocaine, opiates, and amphetamines [47]. Children of alcohol-addicted parents run greater risks to become alcoholics. Thus, frequency of alcohol addiction among adult sons who grew in families with alcohol-addicted parents amounts to $70 \%$; among adult daughters, from 5 to $25 \%$ [48].

A lot of risk factors exert their adverse influence over a certain time lag; on the contrary, alcohol produces negative effects already among people aged 15-29. Mortality among young people caused by alcohol consumption reaches $13.5 \%$. In 2016578,000 deaths of young people were caused by alcohol intake [49].

Low physical activity. Low physical activity is another health risk factor that occurred due to industrial production being modernized and living conditions having changed significantly.

In March 2018 P.A, Kolobkov, the RF Minister for Sport, said that $36.6 \%$ Russians aged 3-79 did some sports. 6 years ago the figure was by $15 \%$ lower, that is, the parameter now is closed to economically developed countries where it is not lower than $40 \%$ [37] and where researchers detect that people, especially young ones, are becoming more and more involved into doing sports, attending sport clubs, and playing sport games [50-52]. According to data provided by VSIOM, over the last ten years sporty lifestyle has become much more popular in Russia. $25 \%$ people in the country do sports regularly, and $30 \%$, from time to time (against $9 \%$ and $17 \%$ in 2008) [53]. A share of schoolchildren and students doing sports has also grown considerably, from $47 \%$ in 2012 to $76.8 \%$ in 2017 [37].

CeDO-2018 yielded the following results: $68 \%$ fathers and $60 \%$ mothers stated that they did some sports; $19 \%$ fathers and $18.8 \%$ mothers did it every day; $38 \%$ and $31.3 \%$ accordingly, several times a week; $10.3 \%$ and $10.2 \%$ accordingly, once a week. About half of parents (42.6\%) thought doing sports to be an integral part of healthy lifestyle (Table 2).
As regards influence exerted by family members on children's health, parents assessed their contribution into their children's health lifestyle quite adequately. Parents who did some sports were inclined to think that they were making their children pursue healthy lifestyle $(62 \%)$. Confidence in it was directly proportionate to frequency of doing sports; there were $73.7 \%$ parents who believed in it among those who did sports every day; $64.7 \%$, among those who did sports several times a week; and $47.8 \%$, among those who did sports once a week. $30.5 \%$ respondents among those who didn't do sports also believed they persuaded their children to pursue healthy lifestyle with their own example.

Improper nutrition and overweight. Nowadays more and more people all over the world suffer from overweight and obesity. D. Callahan enlisted obesity among top five threats to the mankind, along with climatic changes, access to food and water, and diseases [54]. The problem is caused by people being less physically active and a global shift in nutrition rations towards high-energy products with high fat and sugar contents [55]. According to CeDO-2018 data, $93 \%$ parents thought improper nutrition to be a risk factor; $68.8 \%$ out of them believed it was extremely hazardous, and $26.2 \%$, rather hazardous (Table 1).

Overweight usually occurs in childhood and improper nutrition both at school and at home makes for it as children tend to consume a lot of fast food and carbonated drinks. All over the world, a share of children and teenagers aged 5-19 who suffered from overweight and obesity increased from $4 \%$ in 1975 to $18 \%$ in 2016; four out of each five children with the given problem would still have it in their adult life [56].

Nowadays in Russia parents don't think that their children having overweight or being fat is a serious problem and it is often neglected. But as domestic researchers reveal, $26.3 \%$ schoolchildren think they are "too fat" [28]; a share of children aged $0-14$ who suffered from obesity grew by $56 \%$ from 2005 to 2016, and a share of teenagers aged 15-17 who had the same problem, by $47 \%$ [11], and 
we should also note that not each such case is registered as a diagnosed disease.

Risky sexual behavior. Sexual behavior has a specific role in the structure of factors that influence teenagers' health. Teenagers who are deprived of support from their closest social relations run the highest risks. "Parent child" relations are especially significant in this respect and teenagers who are sexually active frequently state they don't have tight personal contacts with their parents. We should note that although most parents $(68 \%)$ admit they can talk with their children about sexual education [57], in reality only $10 \%$ teenagers say that they were first enlightened on sexual matters by their parents [58].

As per data obtained in some domestic research, teenagers on average have their first sexual contact when they are 16.8 years old; about $30 \%$ girls and $45 \%$ boys already have sexual experience by $16 ; 10-13 \%$ children already have it when they are 13-14 years old; and $4-9 \%$ children younger than 13 [59]. The first sexual contact at an early age can produce adverse effects on teenagers' health as it causes high risks of sexual diseases, including HIV, as well as of early unplanned pregnancies and abortions [60-62]. When a teenager starts his or her sexual life too early, it results in much greater chances that in future he or she will not use any contraception [59] and will be prone to promiscuity [62].

Children and teenagers injuries. Injuries are one of the primary risk factors for children as they cause the greatest life-threatening risk and are the primary reason for children becoming disabled all over the world. As per WHO data, about 2,300 deaths among children younger than 18 are caused by injuries, and $90 \%$ of such injuries result from unintentional incidents or casualties [63], most of them being potentially preventable; $88 \%$ of parents in Russia whose children suffered from injuries claim that the last injury could have been avoided [64]. The situation gets even worse due to low living standards of many families in Russia who have certain difficulty with buying or even can't afford to buy such simple things as a car seat for a baby, or specific appliances or devices for providing children's safety at home or outdoors, etc. Together with parents having low competence as regards providing safety environment for their children, it results in much greater risks of children being injured. Children injuries should be prevented and it is necessary to start with adults who are to learn how to control their children's behavior more efficiently and adhere to basic rules for childcare. Medical and social workers, in their turn, are to timely provide parents with relevant information on a situation that can result in an injury; they should also educate parents on safe behavior and on how they can educate their children on the matter.

Conclusion. We have revised literature on the matter, analyzed data obtained via CeDO-2018 and other sociological research on parents influencing their children's health and their adherence to healthy lifestyle as well as parents' role in reducing adverse effects produced by health risk factors. Having done it, we can make the following conclusions:

- adherence to healthy lifestyle appears under influence exerted by the closest relations. A family is a primary institution that influences value orientations of children and teenagers in the sphere of health and healthpreserving behavior;

- children and teenagers' orientation at preserving their health and pursuing healthy lifestyle should be an integral part of family education and should be based both on targeted activities accomplished by parents and aimed at informing children about advantages of healthy lifestyle and on motivating children and teenagers to pursue healthy lifestyle by giving them a personal example;

- parents are not sufficiently aware how to manage health risk factors that threaten their children's health and how to minimize their impacts; adults tend to underestimate influence exerted on their children's health by such behavioral risk factors as improper nutrition, overweight and obesity, and low physical activity;

- it is necessary to develop a reasoned policy aimed at making parents more educated as regards healthy lifestyle; it should include providing them with relevant and scientifically 
grounded data on existing risks for their health and health of their children as well as on how to eliminate them; parents should be provided with such data as it is them who bear the main responsibility for future generations' health;

- the current situation in Russia with children's and teenagers' health is being made even worse by the fact that many families in the country don't have financial and other capabilities to provide basic conditions for preserving their children's health and safety for them; consequently, there should be aid provided directly to families depending on a specific situation;

- it is necessary to accomplish wide-scale modernization of material and technical base and social and cultural infrastructure required for preserving children's and teenagers' health; it includes developing public transports, constructing sport facilities, organizing health nutrition at educational facilities, creating comfortable conditions for studies and leisure etc.;
- making children and teenagers pursue health-preserving behavior requires combined efforts made by basic social institutions aimed at creating a common space where healthreserving competence can be acquired; at educating young people how to pursue healthy lifestyle and eliminating risk factors that threaten their health. All this requires a complex approach involving not only family members but also medical experts, sociologists, psychologists, and representatives of public and social organizations.

Funding. The work has been accomplished due to financial support provided by the RFFR within the research project entitled "Inter-regional studies on life values and intransitivity of attitudes towards having a family and children among women, men, and married couples based on ongoing analysis of comparable data (1976-2020) " No. 18-011-01037.

Conflict of interests. The authors declare there is no any conflict of interests.

\section{References}

1. Rimashevskaya N.M. Russkii krest [The Russian Cross]. Priroda, 1999, no. 6, p. 7-12 (in Russian).

2. Gorshkova I.V., Prokhorov B.B., Tarasova E.V., Shmakov D.I. Obshchestvennoe zdorov'e i ekonomika [Public health and the economy]. Institut narodnogo prognozirovaniya RAN, 2007. In: B.B. Prokhorov ed. Available at: https://ecfor.ru/publication/obshhestvennoe-zdorove-i-ekonomika/ (10.05.2019) (in Russian).

3. Dzhanaeva N.G., Elizarov V.V., Bobkov V.N. Zdorov'e naseleniya kak klyuchevoi factor sotsial'no-ekonomicheskogo razvitiya regionov Rossii [Population health as a key factor in social and economic development of the RF regions]. Analiticheskii vestnik № 34 (518). Nauchno-ekspertnyi sovet pri Predsedatele Soveta Federatsii Federal'nogo Sobraniya Rossiiskoi Federatsii. In: V.D. Krivova ed. Moscow, 2013, pp. 10-17 (in Russian).

4. Sachs J.D. Macroeconomics and health: investing in health for economic development: executive summary. Report of the Commission on Macroeconomics and Health. World Health Organization, 2001, 20 p.

5. Suhrcke M., Arce R.S., McKee M., Rocco L. Economic costs of ill health in the European Region. Health Systems, Health and Wealth: WHO European Ministerial Conference on Health Systems. Estonia, 2008, $24 \mathrm{p}$.

6. Bloom D.E., Canning D., Sevilla J. The Effect of Health on Economic Growth: A Production Function Approach. World Development, vol. 32, no. 1, 2004, pp. 1-13. DOI: 10.1016/j.worlddev.2003.07.002

7. Zhuravleva I.V. Zdorov'e studentov: sotsiologicheskii analiz [Students' health: sociological analysis]. Moscow, Institut sotsiologii RAN Publ., 2012, 252 p. (in Russian).

8. Zhuravleva I.V. Zdorov'e molodezhi: vozmozhno li ego uluchshit'? [Young people's health: is it possible to improve it?]. Rossiya reformiruyushchayasya: ezhegodnik. Moscow, Novyi Khronograf Publ. In: M.K. Gorshkov ed., 2017, no. 15, pp. 419-436 (in Russian).

9. Ulumbekova G.E. Zdravookhranenie Rossii: 2018-2024 gg. Chto nado delat'? [Public healthcare in Russia in 2018-2024: what should be done?]. ORGZDRAV: novosti, mneniya, obuchenie, 2018, no. 1, pp. 9-16 (in Russian). 
10. Zargarova A.E., Vladimirova E.V., Vladimirov V.V., Sachkova O.S. Epidemiology of the incidence of sexually transmitted infections among young people. Sotsial'nye aspekty zdorov'ya naseleniya, 2018, vol. 5, no. 63, pp. 10-11 (in Russian).

11. Zdravookhranenie v Rossii: statisticheskii sbornik [Public healthcare in Russia: a statistical collection]. Moscow, Rosstat Publ., 2017, 170 p. (in Russian).

12. Baranov A.A., Albitskiy V.Yu. State of health of children in Russia, priorities of its preservation and improving. Kazanskii meditsinskii zhurnal, 2018, vol. 99, no. 4, pp. 698-705 (in Russian).

13. Onishchenko G.G., Zaitseva N.V., May I.V., Shur P.Z., Popova A.Yu., Alekseev V.B., Dolgikh O.V., Zemlyznova M.A. [et al.]. Analiz riska zdorov'yu v strategii gosudarstvennogo sotsial'noekonomicheskogo razvitiya: monografiya [Health risk analysis within the strategy for the state social and economic development: a monograph]. In: G.G. Onishchenko, N.V. Zaitseva eds. Moscow, Perm, Izdatel 'stvo Permskogo natsionalnogo issledovatelskogo universiteta Publ., 2014, 738 p. (in Russian).

14. Kiku P.F., Zhigaev D.S., Shiter N.S., Sabirova K.M., Mezentseva M.A. The concept of risk factors for the health of the population. Byulleten' fiziologii i patologii dykhaniya, 2016, no. 62, pp. 101-109 (in Russian).

15. Reshetnikov A.V. Evolyutsiya i problem sovremennoi sotsiologii i meditsiny [Evolution and issues in the contemporary sociology and medicine]. Ekonomika i zdravookhranenie, 2000, no. 11, pp. 24-28 (in Russian).

16. Link B., Phelan J. Social Conditions as Fundamental Causes of Disease. Journal of Health and Social Behavior, 1995, pp. 80-94. DOI: 10.2307/2626958

17. Wilkinson R.G. Socio-economic differences in mortality: interpreting the data on their size and trends. Class and Heath. London, New York, Tavistock Publ., 1986, pp. 1-20.

18. Barg A.O., Nesevrya N.A. Sotsial'nye factory riska zdorov'yu: teoretiko-metodologicheskie problem analiza [Social health risk factors: theoretical and methodological issues of the analysis]. Vestnik Permskogo universiteta. Filosofiya. Psikhologiya. Sotsiologiya, 2010, no. 1, pp. 99-108 (in Russian).

19. Keshishev I.A., Orel O.V., Smirnova V.I. Environment and health of the children's population. Pediatr, 2013, vol. 4, no. 2, pp. 24-27 (in Russian).

20.10 facts on children's environmental health. Available at: https://www.who.int/features/factfiles/children_environmental_health/en/ (10.06.2019).

21. Ekologiya i zdorov'e detei [Ecology and children's health]. In: M.Ya. Studenikin, A.A. Efimova eds. Moscow, Meditsina Publ., 1998, 385 p. (in Russian).

22. Vel'tishchev Yu.E., Mizernitskii Yu.L. Ekologicheskie aspekty pediatricheskoi pul'monologicheskoi patologii [Ecological aspects of pediatric pulmonologic pathology]. Pul'monologiya detskogo vozrasta: problem i resheniya. In: S.Yu. Kaganov, Yu.L. Mizernitskii eds. Moscow, 2001, no. 1, pp. 55-67 (in Russian).

23. Krasnov M.V., Kirillov A.G., Krasnov V.M., Savaskina E.N., Abrukova A.V. Hereditary diseases at children. Prakticheskaya meditsina, 2009, vol. 7, no. 39, pp. 22-30 (in Russian).

24. Nikolaeva E.A., Semyachkina A.N. Sovremennye vozmozhnosti lecheniya nasledstvennykh zabolevanii u detei [Modern possibilities of hereditary diseases treatment in children]. Rossiiskii vestnik perinatologii i pediatrii, 2018, vol. 63, no. 4, pp. 6-14 (in Russian).

25. Nasledstvennye bolezni v populyatsiyakh cheloveka [Hereditary diseases in human populations]. In: E.K. Ginter ed. Moscow, Meditsina Publ., 2002, 304 p. (in Russian).

26. Nazarova I.B. Zdorov'e rossiiskogo naseleniya: factory i kharakteristiki (90-e gody) [Russia's population health: factors and characteristics in the 1990's]. Sotsiologicheskie issledovaniya, 2003, no. 11, pp. 57-69 (in Russian).

27. Kislitsyna O.A. Socio-economic inequality in health: trends and hypotheses. Sotsial'nye aspekty zdorov'ya naseleniya, 2017, vol. 54, no. 2, pp. 1-2 (in Russian).

28. Kuchma V.R., Sokolova S.B. Basic trends in behavioral health risks. Health Risk Analysis, 2019, no. 2, pp. 4-13 (in Russian). DOI: 10.21668/health.risk/2019.2.01.eng

29. Vospitanie detei. Opros naseleniya [How to educate children: opinion poll]. Baza dannykh "FOM», 2004. Available at: http://bd.fom.ru/report/cat/famil/child_dress/dd041823 (18.07.2019) (in Russian).

30. Polunina N.V. Sostoyanie zdorov'ya detei v sovremennoi Rossii i puti ego uluchsheniya [Children's health in Russia: current state and ways for improvement]. Vestnik Roszdravnadzora, 2013, no. 5, pp. 17-24 (in Russian). 
31. Lebedeva-Nesevrya N.A., Barg A.O. Osobennosti vospriyatiya roditelyami vneshnesredovykh i povedencheskikh riskov dlya zdorov'ya detei doshkol'nogo vozrasta [Peculiarities related to how parents perceive environmental and behavioral risks for pre-school children's health]. Vestnik Permskogo universiteta. Filosofiya. Psikhologiya. Sotsiologiya, 2011, no. 1, pp. 101-106 (in Russian).

32. Dostupnost' i kachestvo rossiiskogo zdravookhraneniya: otsenki patsientov [Availability and quality of public healthcare in Russia: estimated by patients]. Moscow, VTsIOM Publ., 2015. Available at: https://wciom.ru/fileadmin/file/reports_conferences/2015/2015-09-02-zdravoohranenie.pdf (10.07.2019) (in Russian).

33. Korp P. Problems of the Healthy Lifestyle Discourse. Sociology Compass, 2010, vol. 4, no. 9, pp. 800-810. DOI: $10.1111 / \mathrm{j} .1751-9020.2010 .00313 . x$

34. V 17\% sluchaev tabak yavlyaetsya prichinoi prezhdevremennoi smertnosti v Rossii [In Russia tobacco smoking is a cause of untimely deaths in $17 \%$ cases]. Ministerstvo zdravookhraneniya Rossiiskoi Federatsii: Ofitsial'nyi sait. Available at: https://www.rosminzdrav.ru/news/2018/11/15/9632-v-17sluchaev-tabak-yavlyaetsya-prichinoy-prezhdevremennoy-smertnosti-v-rossii (10.05.2019) (in Russian).

35. Prevalence of tobacco smoking. WHO: official website. Available at: http://gamapserver.who.int/gho/interactive_charts/tobacco/use/atlas.html (10.05.2019).

36. Inglik T.N., Chernyavskaya N.M., Aibazova L.B. Epidemiologic aspects related to tobacco smoking as risk factors for female workers employed in retail trade. Health Risk Analysis, 2019, no. 1, pp. 109-117 (in Russian). DOI: 10.21668/health.risk/2019.1.12.eng

37. Zdorovyi obraz zhizni: nekotorye vazhnye resheniya i pokazateli za 6 let [Healthy lifestyle: certain important decisions and parameters over the last 6 years]. Pravitel'stvo Rossiiskoi Federatsii: Ofitsial'nyi sait. Available at: http://government.ru/info/32118/(10.04.2019) (in Russian).

38. Sakevich V. Rasprostranennost' kureniya sredi rossiyanok [Prevalence of tobacco smoking among female population in Russia]. Demoskop Weekly, 2014, no. 603-604. Available at: http://www. demoscope.ru/weekly/2014/0603/reprod01.php (14.06.2019) (in Russian).

39. Lewis S., Parrott S., Wormall S., Coleman T. Restarting smoking in the postpartum period after receiving a smoking cessation intervention: a systematic review. Addiction, 2016, vol. 111, no. 6, pp. 981-990. DOI: 10.1111/add.13309

40. Pokatilov A.B., Tirichenko O.Y. Kurenie sredi nesovershennoletnikh [The problem of smoking among teenagers]. Glavvrach Yuga Rossii, 2017, vol. 54, no. 2 (in Russian)

41. Vliyanie roditelei na otnoshenie podrostkov $\mathrm{k}$ kureniyu [How parents influence attitudes towards smoking among teenagers]. Institut sravnitel'nykh sotsial'nykh issledovanii. Available at: http://www.cessi.ru/index.php?id=74 (12.06.2019) (in Russian).

42. Kurenie v sem'e i vozrast nachala kureniya podrostka [Smoking in a family and an age at which a teenager starts smoking]. Institut sravnitel'nykh sotsial'nykh issledovanii. Available at: http://www. cessi.ru/index.php?id=74 (10.05.2019) (in Russian).

43. V Moskve nachal rabotu II Vserossiiskii forum po obshchestvennomu zdorov'yu [The second all-Russia forum on public health has begun in Moscow]. Ministerstvo zdravookhraneniya Rossiiskoi Federatsii: Ofitsial'nyi sait. Available at: https://www.rosminzdrav.ru/news/2018/10/16/9243-v-moskvenachal-rabotu-ii-vserossiyskiy-forum-po-obschestvennomu-zdorovyu (10.05.2019) (in Russian).

44. Global Information System on Alcohol and Health. World Health Organization. Available at: http://apps.who.int/gho/

data/node.main-euro.GISAH?lang=en (10.07.2019).

45. Shcherbakova E.M. Mirovye tendentsii potrebleniya alkogolya, otsenki VOZ 2018 goda [World trends in alcohol intake: WHO estimates in 2018]. Demoskop Weekly, 2019, no. 813-814. Available at: http://demoscope.ru/weekly/2019/0815/barom01.php (07.08.2019) (in Russian).

46. Ot chego nuzhno zashchishchat' nashikh detei [What our children should be protected from]. Infografika VTsIOM. Available at: https://infographics.wciom.ru (10.05.2019) (in Russian).

47. Smith V.C., Wilson C.R. Families Affected by Parental Substance Use. Pediatrics, 2016, vol. 2, no. 138, pp. e20161575. DOI:10.1542/peds.2016-1575

48. Merinov A.V., Lukashuk A.V., Filippova M.D. The prevalence of chemical addictions has «adult children of alcoholics». Tyumenskii meditsinskii zhurnal, 2015, vol. 17, no. 4, pp. 21-24 (in Russian).

49. Global status report on alcohol and health 2018. World Health Organization, 2018, 472 p. Available at: https://apps.who.int/iris/bitstream/handle/10665/274603/9789241565639-eng.pdf?ua=1 (10.05.2019). 
50. Carlman P., Wagnsson S., Patriksson G. Causes and consequences of dropping out from organized youth sports. Swedish Journal of Sport Research, 2013, vol. 2, no. 1, pp. 26-54.

51. Crane J., Temple V. A systematic review of dropout from organized sport among children and youth. European Physical Education Review, 2015, vol. 21, no. 1, pp. 114-131. DOI: 10.1177/1356336X14555294

52. Fraser-Thomas J., Cote J., Deakin J. Understanding dropout and prolonged engagement in adolescent competitive sport. Psychology of Sport and Exercise, vol. 9, no. 5, pp. 645-662. DOI: 10.1016/j.psychsport.2007.08.003

53. Zdorovyi obraz zhizni: monitoring [Healthy lifestyle: monitoring]. Infografika VTsIOM. Available at: https://infographics.wciom.ru/theme-archive/society/social-problems/smoking/article/zdorovyiobraz-zhizni-monitoring.html (10.07.2019) (in Russian).

54. Callahan D. The five horsemen of the modern world: climate, food, water, disease and obesity. New York, Columbia University Press, 2016, 416 p.

55. Global Strategy on Diet, Physical Activity and Health. World Health Organization. Available at: https://www.who.int/dietphysicalactivity/childhood_why/ru/ (10.05.2019).

56. Adolescent obesity and related behaviours: trends and inequalities in the WHO European Region, 2002-2014. In: J. Inchley, D. Currie, J. Jewell, J. Breda, V. Barnekow eds. World Health Organization, 2017, 98 p.

57. Seksual'noe prosveshchenie molodezhi: kak, kogda i zachem? [Sexual education for young people: how, when, and what for?]. Infografika VTSIOM, 2018. Available at: https://wciom.ru/index.php?id $=236 \&$ uid $=9427$ (10.05.2019) (in Russian).

58. Kadoshnikova M.Yu. To the question about the need for sexual education for adolescents and their parents. Zdorov'e i obrazovanie v XXI veke, 2015, vol. 17, no. 1, pp. 111-118 (in Russian).

59. Bruno V.V. Risky Sexual Behavior of Modern Teenagers in Russia. Part I. Sotsiologicheskaya nauka $i$ sotsial'naya praktika, 2018, vol. 6, no. 4 (24), pp. 117-129 (in Russian). DOI: 10.19181/snsp.2018.6.4.6089/

60. Epstein M., Manhart L.E., Hill K.G., Bailey J.A., Hawkins J.D., Haggerty K.P., Catalano R.F. Understanding the link between early sexual initiation and later sexually transmitted infection: test and replication in two longitudinal studies. Journal of Adolescent Health, 2014, vol. 54, no. 4, pp. 435-441. DOI: 10.1016/j.jadohealth.2013.09.016

61. Stöckl H., Kalra N., Jacobi J., Watts C. Is Early Sexual Debut a Risk Factor for HIV Infection Among Women in Sub Saharan Africa? A Systematic Review. American Journal of Reproductive Immunology, 2013, vol. 69, no. 1, pp. 27-40. DOI: 10.1111/aji.12043

62. Shafii T., Stovel K., Davis R., Holmes K. Is condom use habit forming? Condom use at sexual debut and subsequent condom use. Sexually transmitted diseases, 2004, vol. 31, no. 6,pp. 366-372. DOI: 10.1097/00007435-200406000-00010

63. 10 faktov o detskom travmatizme [10 facts about children's injuries]. Available at: https:// www.who.int/features/factfiles/injuries_children/facts/ru/ (10.05.2019) (in Russian).

64. Gorbunov V.I., Gorbunov M.V., Pluzhnik V.I. The medical social aspects of childhood traumatism accounting the family type. Problemy sotsial'noi gigieny, zdravookhraneniya i istorii meditsiny, 2012, no. 3, pp. 25-27 (in Russian).

Novoselova E.N. Role played by a family in creating healthy lifestyle and eliminating risk factors that cause threats to children's and teenagers' health. Health Risk Analysis, 2019, no. 4, pp. 175-185. DOI: 10.21668/health.risk/2019.4.19.eng

Received: 15.04 .2019

Accepted: 27.11 .2019

Published: 30.12.2019 